\title{
Organoleptic, minerals and vitamins' evaluation of some Nigerian breads
}

\author{
O. A. T. Ebuehi*, O. O. Owolabi, C. E. Ikanone, I. T. Amabibi and A. P. Ajekwu \\ Department of Biochemistry, College of Medicine, University of Lagos, \\ P.M.B. 12003, Lagos, Nigeria. \\ *Address correspondence, E-mail: ebuehi@yahoo.com
}

\begin{abstract}
The organoleptic, minerals and vitamins' evaluation of some Nigerian breads were investigated. Five commonly consumed breads in Lagos, Nigeria, which were used for the study. These were Val-U, Nourish, Big-Treat, Unilag and Agege breads. These breads were purchased from reputable outlets within $24 \mathrm{~h}$ of production. Organoleptic or sensory evaluation of the bread samples was carried out using 5-point hedonic scale and 20 panelists, who were regular consumers of bread. The appearance, odour, taste, texture and general acceptability were scored. Mineral concentrations of $\mathrm{Cu}^{2+}, \mathrm{Na}^{+}, \mathrm{Zn}^{2+}, \mathrm{Ca}^{2+}, \mathrm{Mg}^{2+}$, $\mathrm{Mn}^{2+}, \mathrm{K}^{+}$and $\mathrm{Fe}^{2+}$ ions in the bread samples were determined using atomic absorption spectrophotometer. Vitamins A, $B_{1}, B_{2}$ and $B_{6}$ levels in the bread samples were analyzed by high performance liquid chromatography.

The percentage mean sensory score of appearance, odour,

had the lowest score of $60.0 \%$. Val-U bread contained the highest concentrations of minerals, while Big-Treat White and Agege breads had the lowest mineral levels. The vitamin A level in Big-Treat White bread was significantly $(\mathrm{p}<0.01)$ higher as compared to other bread samples. There was little or no Vitamin $\mathrm{B}_{1}, \mathrm{~B}_{2}$ and $\mathrm{B}_{6}$ in some of the Nigerian breads. Big-Treat White bread was the most preferred, followed by Nourish and Unilag breads, while Agege bread was least preferred of the breads. The Nigerian breads were rich in minerals and vitamin $\mathrm{A}$ and the nutrient composition of these breads may have influenced their consumers' preference and general acceptability.

In conclusion, Nigerian breads are rich in some micronutrients especially vitamin A, calcium, magnesium and potassium, which are essential for normal growth and health of humans.
\end{abstract} taste, texture, and general acceptability of these breads were between 84.0 and 60.0. Big-Treat White bread recorded the highest score of $84.0 \%$ while Agege Bread
Keywords: Nigerian breads, organoleptic, minerals and vitamins, evaluation

\section{INTRODUCTION}

$\mathrm{B}_{\mathrm{h}}^{\mathrm{re}}$ read is a major wheat based product, which has gained wide consumers' acceptance for many years in Nigeria. (Badifu et al., 2005, Abulude, 2005). The product is basically made of hard wheat flour, yeast, fat, sugar, salt, and water Gayle et al., 1986). Bread is a good source of nutrients, such as, important vitamins and minerals. It is predominantly rich in carbohydrates and also a vehicle for food fortification of essential micronutrients. Wheat and rye flours are the only flours that contain gluten (elastic protein) forming proteins, which helps make raised loaves. Bread, whole wheat, all-purpose flour and other wheat flours are perfect to use in bread recipes, because they all contain ample gluten - forming proteins, bread being the highest. Higher protein flour makes more gluten and lighter yeast breads. ( Gayle et al, 1986 Badifu and Aka, 2001).

Flour is fortified with vitamins and minerals to make up for those lost during processing. Ingredients, such as egg, yeast, milk, salt and water 
contain or as the case may be fortified with various vitamins and minerals. For example, salt is fortified with iodine, water is fortified with minerals such as fluorine, manganese, magnesium etc, milk contains vitamin A, eggs contain some B-complex vitamins, and so on. Bread can be eaten plain or topped with butter, margarine or jam, as a breakfast meal. Therefore, all these nutrients contribute to the total nutritive value of bread. (Gayle et al., 1986, Kent, 2002).

Bread celebrates the richest and simplest pleasures of daily living. In most European cultures, it is the single inevitable presence at the table during all three meals of the day, for very few would contemplate a meal without bread (Kent, 2002). Bread is a food product made of flour or meal that is moistened, kneaded and sometimes fermented and then usually baked into loaves or cakes. It is universally accepted as a very convenient form of food that has demonstrated characteristics desirability to all population, rich and poor, rural and urban. It may contribute as much as $18 \%$ of total protein, $17 \%$ of nicotinic acid, $20 \%$ vitamin $\mathrm{B}_{1}, 13 \%$ of calcium and about $18 \%$ iron in the diets of many persons. Examples of different bread types include white, brown, whole meal, wheat germ, French malt, milk, skimmed milk, protein and gluten bread. (He and Hoseney, 1992).

There are several brands of bread produced in Nigeria, especially in Lagos, the commercial nerve centre of the country. The most commonly consumed bread in Lagos include Agege, Big Treat, Big Treat wheat, Nourish, Butter field, Val-U, Unilag, Wilson's and UTC, to mention but a few. There is paucity of information on the nutritive composition of breads produced in Nigeria. Therefore, the objective of the study is to conduct the organoleptic, mineral and vitamin evaluation of some popularly consumed breads in Lagos, Nigeria.

\section{MATERIALS AND METHODS}

\section{Selection of bread brands}

Five commonly consumed breads in Lagos, Nigeria, were selected using well-structured questionnaires. These bread brands selected and used for the study were Val-U, Nourish, BigTreat white, University of Lagos (Unilag) and Agege. These breads were purchased from reputable outlets in Lagos, Nigeria; within 24h of production. Organoleptic or sensory evaluation of bread brands

Organoleptic evaluation of Val-U, Nourish, BigTreat, Unilag and Agege breads were carried out using 5-point Hedonic scales, by the method of Larmond (1977). The appearance, odour, taste, texture and general acceptability were scored and 20 panelists who were regular consumers of bread were used. The panelists were instructed to taste the bread samples and rinse their mouth after each sample taste. They were requested to express their feelings about the samples by scoring the organoleptic attributes using the Hedonic scale (1; dislike extremely , 2 ; dislike , 3 ; neither like nor dislike , 4 ; like and 5 ; like extremely ).

\section{Mineral evaluation of bread brands}

The concentrations of selected minerals in the bread brands, such as copper, sodium, zinc, calcium, magnesium, manganese, potassium and iron ions were determined using Pye Unicam Atomic Absorption spectrophotometer, while sodium and potassium ions levels were determined using flame photometer. The minerals were estimated after wet oxidation of $2 \mathrm{~g}$ sample using concentrated $\mathrm{HNO}_{3}$ and perchloric acid, as described by Osborne and Voogt (1978).

\section{Vitamin assay of bread brands}

Vitamins $A, B_{1}, B_{2}$ and $B_{6}$ levels in the selected bread brands were assayed using high performance liquid chromatography. Standard pure vitamins A, $\mathrm{B}_{1} \mathrm{~B}_{2}$ and $\mathrm{B}_{6}$ were purchased from SigmaChemicals, USA and the standard vitamin solutions prepared in appropriate buffers were used for the assay.

\section{Statistical analysis}


Differences between means were assessed by Students t-test, while the levels of significance of the data were computed by analysis of variance according to Steel and Torrie (1981).

\section{RESULTS AND DISCUSSION}

Results of the organoleptic attributes of the bread brands used in this study are presented in Table I. The percentage mean sensory scores of appearance, odour, taste, texture and general acceptability of Val-U, Nourish, Big-Treat, Unilag and Agege breads were between 84.0 and 60.0. The Big-Treat white bread was the most preferred and had the highest score of $84.0 \%$, while Agege bread was the least preferred, with the lowest score of $60.0 \%$ (Table I).

Results of the mineral composition of some Nigerian bread brands are shown in Table 2. The following minerals $\mathrm{Cu}^{2+}, \mathrm{Na}^{+}, \mathrm{Ca}^{2+}, \mathrm{Mg}^{2+}, \mathrm{Mn}^{2+}, \mathrm{K}^{+}$and $\mathrm{Fe}^{2+}$ were detected and quantified in all bread brands investigated. The levels of these minerals were high in all the bread brands, with Val-U and Unilag breads containing the highest concentrations of these minerals, while Big-Treat White and Agege bread had the lowest levels (Table 2). However, the levels of $\mathrm{Cu}^{2+}, \mathrm{Zn}^{2+}, \mathrm{Mn}^{2+}$ and $\mathrm{Fe}^{2+}$ were significantly very low in all the bread brands. These breads are good sources of $\mathrm{Na}^{+}, \mathrm{Ca}^{2+}, \mathrm{Mg}^{2+}$, and $\mathrm{K}^{+}$as compared with the recommended dietary allowances (RDA) (Wardlaw, 1999, Tahvoven and Kumpulainen,1994 ) .

Some of these present findings in the mineral composition of Nigerian breads corroborate previous reports of Abulude (2005);). It is important to mention that the levels of these minerals determined in these Nigerian breads were all below the recommended WHO maximum contamination levels (WHO, 1984).

The concentrations of vitamins $\mathrm{A}, \mathrm{B}_{1}, \mathrm{~B}_{2}$, and $\mathrm{B}_{6}$ in some of the Nigerian breads are presented in Table 3. The vitamin A level in Big-Treat white bread was significantly $(p<0.01)$ the highest as compared to other breads. The Nigerian breads are predominantly rich in vitamin $\mathrm{A}$. There were little or no vitamins $B_{1}, B_{2}$, and $B_{6}$ in most of these Nigerian breads (Table 1 ).

The variation in the nutrient composition of these breads may be due to source and composition of ingredients, baking procedures, storage, transportation and production condition, and these may influence the organoleptic attributes, consumers' preferences and overall acceptability. The metabolic functions of minerals for life cannot be overemphasized and has been extensively reported in literature (Goodhart and Shils, 1980, Champe and Honey, 1994). Both copper and iron are required in mammalian nutrition to prevent anemia. Similar to zinc, copper also forms metalloproteins and enzymes from which copper cannot be dissociated without loss of activity (Champe and Harvey 1994). Calcium is an important constituent of body fluids and bone formation, in conjunction with phosphorus. Magnesium is an activator in enzyme systems, which maintains electrical potential in nerves, sodium and potassium influences osmotic pressure and contributes to normal $\mathrm{pH}$ equilibrium(Cerklewski, 1997).

It may be suggested that consumption of these Nigerian breads would promote vision; since they are rich in vitamin A. Vitamin A, a fat soluble vitamin is a component of the visual pigments of rod and cone cells (Champe and Harvey, 1994). In addition, consumption of these breads may stimulate appetites, possibly because of keratinization of the taste buds and promotes bone growth and reproduction. Vitamin A has been implicated to support spermatogenesis in the male and prevents fetal reabsorption in the female (Goodman, 1980). It has also been to shown to regulate biosynthesis of glycoprotiens which are common constituents of cell membranes.

Thiamine (Vitamin $\mathrm{B}_{1}$ ) and riboflavin (vitamin $\mathrm{B}_{2}$ ) are energy-releasing water-soluble vitamins, since they are the precursor of coenzymes, thiamine 
pyro-phosphate (TPP) and flavine adenine dinucleotide (FAD) respectively. Both TPP and FAD are bound to enzymes that catalyze the oxidation or reduction of substrates. Pyridoxine (Vitamin $\left.\mathrm{B}_{6}\right)$ is the precursor of pyridoxal phosphate which functions as coenzyme for transamination, decarboxylation, deamination and condensation. TPP is required for decarboxylation reactions in the degradation of carbohydrates, and assists in the biosyntheses of antibodies and some amino acids. The present findings indicate that these Nigerian breads contain little qualities of water soluble vitamins.

\section{CONCLUSION}

Nigerian breads are rich in some micronutrients, especially vitamin A, calcium, magnesium and potassium which are essential for normal growth, health and therefore suitable for human consumption.

\section{ACKNOWLEDGEMENTS}

The authors are grateful to all taste panelists who participated in the organoleptic evaluation and to the staff of Bato Chemicals Ltd, Lagos, for their technical assistance.

Table 1: Organoleptic attributes and scores of some Nigerian breads

\begin{tabular}{lccccc}
\hline Organoleptic Attribute & $\begin{array}{l}\text { Big-Treat White } \\
\text { Bread }\end{array}$ & $\begin{array}{l}\text { Nourish } \\
\text { Bread }\end{array}$ & $\begin{array}{l}\text { Unilag } \\
\text { Bread }\end{array}$ & $\begin{array}{l}\text { Val-U } \\
\text { Bread }\end{array}$ & $\begin{array}{l}\text { Agege } \\
\text { Bread }\end{array}$ \\
\hline Appearance & 5 & 4 & 4 & 3 & 3 \\
Odour & 4 & 4 & 3 & 3 & 3 \\
Taste & 4 & 3 & 3 & 4 & 3 \\
Texture & 4 & 4 & 3 & 3 & 3 \\
General acceptability & 4 & 4 & 4 & 3 & 3 \\
\% Mean score & 84 & 76 & 68 & 64 & 60 \\
Position & 1 st & 2nd & 3 rd & 4 th & 5 th \\
\hline
\end{tabular}


Table 2: Mineral composition of some Nigerian breads

\begin{tabular}{llllll}
\hline $\begin{array}{l}\text { Mineral Conc. } \\
(\mathbf{m g} / \mathbf{k g})\end{array}$ & $\begin{array}{l}\text { Big Treat } \\
\text { White bread }\end{array}$ & $\begin{array}{l}\text { Nourish } \\
\text { bread }\end{array}$ & $\begin{array}{l}\text { Unilag } \\
\text { bread }\end{array}$ & $\begin{array}{l}\text { Val-U } \\
\text { bread }\end{array}$ & $\begin{array}{l}\text { Agege } \\
\text { bread }\end{array}$ \\
\hline $\mathrm{Cu}^{2+}$ & 3.066 & 2.766 & 10.596 & 0.799 & 0.406 \\
$\mathrm{Na}^{+}$ & $7.166 \times 10^{3}$ & $5.485 \times 10^{3}$ & $10.438 \times 10^{3}$ & $20.060 \times 10^{3}$ & $15.021 \times 10^{3}$ \\
$\mathrm{Zn}^{2+}$ & 8.172 & 26.551 & 26.31 & 656.553 & 3.734 \\
$\mathrm{Ca}^{2+}$ & 942.402 & 1903.558 & 1485.177 & 1573.11 & 1748.1 \\
$\mathrm{Mg}^{2+}$ & 555.723 & 666.158 & 1899.244 & 3052.249 & 604.213 \\
$\mathrm{Mn}^{2+}$ & 9.0476 & 17.6635 & 20.0276 & 65.0353 & 22.2244 \\
$\mathrm{~K}^{+}$ & 410.467 & 839.454 & 689.392 & 2248.1 & 524.49 \\
$\mathrm{Fe}^{2+}$ & 2.738 & 11.129 & 42.413 & 53.737 & 6.294 \\
\hline
\end{tabular}

Table 3: Vitamins $A, B_{1}, B_{2}$ and $B_{6}$ contents in some Nigerian breads.

\begin{tabular}{llllll}
\hline Vitamin Conc. & $\begin{array}{l}\text { Big-Treat } \\
\text { White bread }\end{array}$ & $\begin{array}{l}\text { Nourish } \\
\text { bread }\end{array}$ & $\begin{array}{l}\text { Agege } \\
\text { bread }\end{array}$ & $\begin{array}{l}\text { Unilag } \\
\text { bread }\end{array}$ & $\begin{array}{l}\text { Val-U } \\
\text { bread }\end{array}$ \\
\hline Vit. A $(\mathrm{IU} / \mathrm{kg})$ & $1,077,359.18$ & $523,724.10$ & $704,424.45$ & $596,870.01$ & $471,583.60$ \\
Vit. $\left.\mathrm{B}_{1} \mathrm{mg} / \mathrm{kg}\right)$ & - & - & 36.947 & 31.3766 & 14,145 \\
Vit. $_{2}(\mathrm{mg} / \mathrm{kg})$ & 2.5341 & - & - & - & 1.476 \\
Vit. $\mathrm{B}_{6}(\mathrm{mg} / \mathrm{kg})$ & - & 8.06 & - & - & - \\
& & & & & \\
\hline
\end{tabular}




\section{REFERENCES}

Abulude, F. O. (2005). Distribution of selected minerals in some Nigerian white bread. Nig. Food Journal Vol. 23, p 139 - 143.

Badifu, G. I. O. and Aka, S. (2001) Evaluation of performance of shea fat as a shortening in bread making. J. Food Sci. Technol. 39: 149 - 151.

Badifu, G. I. O., Chima, C.E, Ajayi Y. I. and Ogoro, A. F. (2005). Influence of mango mesocarp flour supplementation on micronutrient, physical and organoleptic qualities of wheat based bread. Nig. Food J., Vol. 23, p 59-68.

Cerklewski, F. (1991) Handbook of nutritionally essential minerals, Marcel Dekker, Inc., New York, U.S.A, p $583-602$.

Champe, P. C. and Harvey, R. A. (1994) Lippincott's illustrated Reviews: Biochemistry, $2^{\text {nd }}$ ed., Lippincott Raven Publishers, Philadelphia, USA, p 303 - 340

Dhopeshwarkar, G. A. (1983) Nutrition and brain development, Plenum Press, New York, USA, p $85-128$

Gayle, P. E.; Knight, E. M; Adkins, J.S. and Harland B. F. (1986) Nutritional and organoleptic evaluation of wheat bread supplemented with pigeon pea.Cereal Chem. 63: 136-138.

Goodhart, R. S. and Shils, M. E. (1980). Modern Nutrition in health and Disease. $6^{\text {th }}$ ed., Lea \& Febiger, Philadelphia, USA, p 150-325.
Goodman, D. S. (1980). Vitamin A metabolism, Fed. Proc. 39, 2716

Kent, J. (2002) Technology of wheat, 5th ed., Pergaman press, Oxford, p109 - 136.

Larmond, A.L.( 1977) . Laboratory methods for sensory evaluation of food publication No.1637, Dept. of Agric ., Ontario, Canada.

Osborne, D.R. and Voogt, P. (1978). The analysis of nutrients in foods. Academic press, London, $\mathrm{p}$ $166-182$.

Steel, R.G. and Torrie, J. H. (1981). Principles and Proceduces of statistics. Abiomedical approach, 2nd ed., M. C. Graw-Hill, International, Auckland, p50 -110 .

Tahroven, K. and Kumpalainen J. (1994) Levels of selected elements in Finish breads. Journal of Food Composition and Analysis $7: 83$ - 93.

Wardlaw, G. M. (1999). Perspectives in Nutrition, 4th ed., McGraw Hill, USA, p475 - 494.

WHO (1984). Guidelines for drinking water quality, Vol. 2 , Health criteria and other supporting information, Geneva.

Wolf G., Korpe, T. C.; Masu-shipe, S., Schreiber, J. B. , Smith, M. J. and Anderson, R.S. (1979) . Recent evidence for participation of vitamin A in glycoprotein synthesis.

Fed. Proc. 38, 2540. 